\title{
The Mediation Effect Firm Performance on Green Innovation and Firm Value: Evidence the Mining Industry
}

\author{
Andi Auliya Ramadhany ${ }^{*}$,Andi Hidayatul Fadlilah², Maya Richmayati ${ }^{3}$, Ita Mustika ${ }^{4}$, Septa Diana \\ Nabella ${ }^{5}$
}

1,2,3,4,5 Universitas Ibnu Sina, Batam, Indonesia

*Corresponding Author: andi.auliya@uis.ac.id

Article History: Received: 10 November 2020; Revised: 12 January 2021; Accepted: 27January 2021; Published online: 05April 2021

\begin{abstract}
Global warming is currently an issue that is widely discussed of both the accounting literature and others. The topic of environmental performance is gaining increasing attention from academics and politics when it is associated with each country's policies regarding environmental damage. Purpose: This article to investigate both the direct and indirect the effect of green innovation and firm value on financial performance as mediating variable Design/methodology/approach: The samples in this study are applied using purposive sampling ad obtained total sample of PROPER participating companies listed in Indonesia Stock Exchange during the year of 2012-2018. The data used in this study are secondary data obtained from annual report. Companies are listed on the Indonesia Stock Exchange in mining industry in 2012-2018. The variable green innovation was measured by using PROPER, the financial performance was measured by ROA and the firm value were measured by Tobin's Q. Data processing uses SEM-PLS with WarpPLS 6.0 with the consideration that SEM-PLS is a reliable tool for testing predictive models. Several studies using capital market data in Indonesia have found data with abnormal distribution, so data using PLS is appropriate. Result of the study: The authors find that the green innovation has a positive effect on the firm value and financial performance full mediate the effect green innovation and firm value. Research limitations: this article only examines green innovation using the PROPER measure while the green innovation measure is thought to be related to company value such as ISO 14001, content analysis is not discussed at all in this article and the research sample is limited to mining companies. This scope may not be able to describe the overall conditions in Indonesia. Originality/value: This study comprehensively examines both direct and indirect effect of green innovation with financial performance and firm value, which is rarely examined in extant studies.
\end{abstract}

Keywords:Mediation Effect Firm Performance, ReenInnovation, Firm Value Industry

\section{Introduction}

Environmental innovation is now an issue discussed in the accounting literature and others. This topic increases from academics and politics when it is related to each country's policies regarding environmental damage[1]. Environmental damage which is caused by the implementation of mining activities that do not pay attention to environmental conditions has caused an increase in the area of critical land[2]. Walhi East Java reported on its official in 2016 there were 608,913 hectares of forest land in East Java experiencing environmental damage due to excessive exploitation of mines. Walhi Aceh recorded the total area of critical land in Aceh to be 460,099 hectares in addition to damaging the coal mining ecosystem in Bengkulu, causing damage to the watershed, resulting in reduced clean water supply[3].

Increasing cases of environmental damage due to mining activities are becoming a concern of the business world, because people are increasingly concerned about social and environmental issues, thus demanding companies to carry out social and environmental responsibilities. This encourages the creation of green innovation to reduce environmental damage[4][5]. Environmental performance is the company's effort to meet the expectations of various stakeholders for the availability of transparent and accountable information. This is consistent with stakeholder theory which concludes that environmental stewardship is interpreted as a form of corporate communication in bridging and harmonizing the different interests of stakeholders[6]. Several studies reveal the motivation of companies to do green innovation, namely external party pressures and the availability of corporate financial resources in allocating environmental costs, reveals OECD Countries (Austria, Denmark, Finland, France, Germany, Italy, Japan, the Netherlands, Sweden, Switzerland, the United Kingdom, and the United States) carried out green innovation in the presence of political issues. Revealed an increase in purchasing power in Malaysia because the company has been producing environmentally friendly products. Companies that care about the environment in their operations get added value to attract investors[7][8].

Green innovation is an indicator of company performance in creating better environmental conditions through effective and efficient management mechanisms. Green innovation is used in the company's operational activities in the form of environmentally friendly processes and products to enhance the company's competitiveness including innovation in technology, such as energy savings, pollution prevention, recycling, 
waste production or environmentally friendly company management[9]. Green innovation can improve company performance, because it reduces the environmental impact during the product cycle, meets market needs, is the key to achieving growth and environmental sustainability and helps companies deal with the environment to develop new market opportunities. Investment in the environment increases a company's burden in the short term, but increases future profits to increase investor confidence and confidence[10]. Company value can be seen from the movement of stock prices. If the higher the stock price is, the higher the company's value and the higher the attractiveness for investors or potential investors in investing their funds. The inconsistency of previous research raises the opportunity for variables that mediate the effect of environmental performance on company value, namely financial performance[11]. Financial performance is the main indicator of the management control system which has shifted from a financial performance model to a social and environmental performance model because it combines the expectations of various stakeholders, such as shareholders, customers, employees and so on[12][13]. This research was conducted to determine the mediating effect of financial performance on the effect of green innovation on company value, bearing in mind that not all companies in Indonesia participate in government programs. In addition, the study was conducted to see the inconsistencies of the results with previous studies[14][15].

\section{Literature Review and Hypothesis Development}

\subsection{Theory of Stakeholder}

Stakeholder theory helps company managers understand stakeholder environment in managing the environment more effectively and efficiently. Chang, (2011) and Doran \& Ryan, (2016), revealed that the role of stakeholders is important when companies will conduct green innovations to reduce negative impacts on the environment, namely environmental issues involving the interests of various groups in society that can disrupt their quality of life, the era of globalization has pushed the traded products to be environmentally friendly. Investors tend to choose companies that own and develop environmental policies and programs and Social Institutions (NGOs) and environmentalists are increasingly vocal in criticizing companies that have not implemented green innovation (Osazuwa\& Che-Ahmad, 2016).

\subsection{Green Innovation and Firm Value}

Sabrin et al., (2016) stated that company performance has a positive effect on company value. Sabrindkk., (2016), investors expect dividend payments when profitability is high. Rubera \& Kirca, (2017), revealed that innovation can increase company value, because companies are able to utilize resources effectively and efficiently (Berzkalne, I., \& Zelgalve, 2014), (Usman et al., 2017), (Warusawitharana, 2015 ), (Guenster et al., 2011), (Osazuwa \& Che-Ahmad, 2016). Schueth, (2003), revealed that a company that is run must produce improvements to the environment because at present it is impossible to work without caring about the community and the environment. Based on the description, this research develops the following hypotheses:

H1 : Green Innovation has a positive effect on firm value

\subsection{Green Innovation and financial performance}

Stakeholder theory reveals that the company will inform all forms of responsibility for activities carried out related to the environment. Financial performance is an important indicator for investors in measuring the success of a company. Environmental performance of the company's efforts to reduce negative impacts on the environment. Investors expect returns on their investments. Return is obtained if the Corporate is able to produce good performance. Rosli \& Sidek (2013), revealed that green innovation has a positive effect on financial performance (Camisón \& Villar-López, 2014), (Weng et al., 2015), (Singh et al., 2016), (Arenhardt et al., 2016), (Hojnik \& Ruzzier, 2017), (Saedi \& Othman, 2017), (Usman et al., 2017), (Tang et al., 2017), (Rajapathirana \& Hui, 2017), (Xie et al., 2019 ).However, Dangelico \& Pujari (2010), revealed that not all companies can create environmentally friendly industries, because they require high costs, prices are too high to be offered in the market and the company profits decrease (RJ Lin et al., 2014), (Santos et al., 2014). Environmental performance by Corporates to avoid protests or environmental penalties, increase productivity, enhance corporate reputation, foster green awareness, develop new markets, and achieve competitive advantage first mover (YS Chen et al., 2006). Referring to the theory and empirical evidence of previous research, the hypothesis in this study is

$\mathrm{H} 2$ : Green innovation has a positive effect on financial performance

\subsection{Green Innovation, Financial Performance and Firm Value}


Financial performance is a key indicator of the management control system which has shifted from a financial performance model to a social and environmental performance model because it combines the expectations of various stakeholders, such as shareholders, customers, employees and so on (ER Freeman, 2011), (Ezzi \& Jarboui , 2016). Company performance is an important indicator for investors in company performance mediating the influence of green innovation and corporate value (Rajapathirana \& Hui, 2017), (Chan et al., 2016). Environmental innovation that has been carried out by companies can increase competitive advantage and company performance (YS Chen et al., 2006), (Lee et al., 2012), (Rosli \& Sidek, 2013), (R. Lin et al., 2013), (R.-H. Chen, 2014), ( Quoc Duy \& Hong Tuan, 2014), (Karabulut, 2015), (Weng et al., 2015), (Ezzi \& Jarboui, 2016), (Singh et al., 2016), (Mohd Suki, 2017), (Miroshnychenko et al., 2017), (Saedi \& Othman, 2017), (Tang et al., 2017). Based on the description, this research develops the following hypothesis

H3: Green innovation has a positive and significant effect on corporate value through financial performance

\subsection{Financial Performance and Firm Value}

Financial performance is very meaningful for the sustainability of the company (Sabrin et al., 2016). Increased earnings per share attracting investors to invest can increase the value of the company (Ulum, 2015), (Sabrin et al., 2016), (Sucuahi\&Cambarihan, 2016), (Usman et al., 2017), (Sulastri et al., 2018), (Tariq et al., 2019). Sabrin et al. (2016) and Kurniasari\&Warastuti (2015), provide empirical evidence that profitability has a significant positive effect on firm value. The results of previous studies are not consistent with research conducted by Manopo\& Arie (2016) Sulastri et al. (2018) Kurniasari et al. (2018), shows that profitability has a negative effect on the firm value, this is due to the general view of shareholders regarding the prosperity obtained from their investments based solely on share prices rather than accounting earnings as informed by the company. Based on empirical evidence, the hypotheses in this study are:

H4: Financial Performance has a positive effect on Corporate Value

\section{Research Methods}

\section{Population and Sample}

The population in this study is the mining industry registered on the Indonesia Stock Exchange in 2012-2018. Research samples are companies that publish annual reports and data used in this study are available. The sampling technique is to use saturated samples. Saturated sampling is a sampling technique when all members of the population are used. The company's annual report in this study is accessed from the website www.idx.go.id. The following Table 1 presents a list of the number of research samples.

Table 1. Research Samples

\begin{tabular}{clccccccc}
\hline No & \multicolumn{1}{c}{ Criteria } & 2012 & 2013 & 2014 & 2015 & 2016 & 2017 & 2018 \\
\hline 1 & $\begin{array}{l}\text { Mining companies listed on the } \\
\text { Indonesia Stock Exchange }\end{array}$ & 30 & 32 & 31 & 30 & 29 & 30 & 31 \\
& & & & & & & & \\
2 & & 8 & 10 & 9 & 8 & 7 & 8 & 10 \\
2 & Incomplete Company data & 22 & 22 & 22 & 22 & 22 & 22 & 21 \\
\hline & Total & & & & & & &
\end{tabular}

Source: data processed, 2020

Green innovation refers to improvements in manufacturing processes and systems to reduce negative impacts on the environment, such as energy savings, pollution prevention, waste recycling and others (Dangelico\& Pujari, 2010) measured using PROPER with a value of 1 to 5, 1 for companies that get black PROPER, 2 companies get red PROPER, 3 companies get blue PROPER, 4 companies get green color and 5, for companies that get gold PROPER, (Sarumpaet et al., 2017), (Deswanto et al., 2018); (Soewarno et al., 2018). The method for calculating environmental performance based on the PROPER rating is as follows:

Gold, environmental performance: very good, given a PROPER score $=5$

Green, environmental performance: Very good, given a PROPER score $=4$

Blue, environmental performance: good, given a PROPER score $=3$

Red, environmental performance: Poor, given a PROPER score $=2$

Black, environmental performance: very bad, given a PROPER score $=1$

Financial performance is the result of the achievements achieved by each company in running each of their businesses within a certain period of time in the financial unit. Company performance is measured based on financial performance, namely ROA (Return on Assets) 


$$
R O A=\frac{\text { Net profit }}{\text { Total Assets }}
$$

Company value is the level of success of a company in managing its resources based on the assessment of investors. Firm value is measured based on market performance with tobin's q (Chung \& Pruitt, 2007)

$$
\text { Tobin's } Q=\frac{B V T A-B V C E+M V C E}{B V T A}
$$

The analysis used in the data processing in this study was PLS-SEM with statistical software tools WarpPLS 6.0 (Solimun \& Ratmono, 2013). Partial least square method in this study aims to see the effect between variables. The independent variable is green innovation which is proxied by PROPER. Intervening variable financial performance which is proxied by ROA (Return On Asset). The dependent variable, which is the company's value is proxied by Tobin's $\mathrm{Q}$. The statistical model of this study is:

$\mathrm{FV}_{\mathrm{it}}=\alpha_{\mathrm{o}}+\beta_{1} \mathrm{GPI}_{\mathrm{it}}+\beta_{2} \mathrm{FS}_{\mathrm{it}}+\beta_{3} \mathrm{FA}_{\mathrm{it}}+\varepsilon_{\mathrm{it}}$

$\mathrm{FP}_{\text {it }} \quad=\alpha_{\mathrm{o}}+\beta_{1} \mathrm{GPI}_{\mathrm{it}}+\varepsilon_{\mathrm{it}}$

\section{Research Results and Discussion}

\subsection{Inner Model Testing}

Measurement of the inner model is intended to predict the role of financial performance on the influence of green innovation on firm value. Measurement of the inner model in terms of the adjusted R Square value is by considering the Q-Square value. The following inner model tests will be presented in Table 2 below:

Table 2. Results of Inner Model Outputs

\begin{tabular}{lll}
\hline Dependent Variable & adjusted R & Q-Square \\
\hline Financial Performance (ROA) & 0.086 & 0.483 \\
Firm Value (Tobin'S Q) & 0.108 & 0.586 \\
\hline Source: Processed data, 2020 & &
\end{tabular}

Source: Processed data, 2020

Based on Table 2 above, it is shown that financial performance or ROA has an adjusted $\mathrm{R}^{2}$ value of 0.086 or $8.6 \%$. This means that the green innovation variable is able to explain the company's financial performance of $8.6 \%$ while the rest is explained by other variables not used in this study.Firm value has an adjusted $\mathrm{R}^{2}$ value of 0.483 or $48.3 \%$ which means that green innovation is able to explain the value of the company at $48.3 \%$ while the rest is explained by other variables not used in this study. Q-square value or commonly called stoner-geisser coefficient indicates that the independent variable in this research is Green Innovation which has good predictive validity because the Q-square value> 0 .

\subsection{Model Fit Testing}

This study uses four fit model sizes including: Average Path Coefficient (APC), Average R-Square (ARS), Average Adjusted R-Square (AARS) and Average Block Variance Inflation Factor (AVIF). AARS is used to measure the average value of the path coefficient, R-squared and adjusted R-square produced in the model. The four sizes of the fit model are measured based on the required $\rho$-value $\rho \leq 0.05$ [67], [68]. While AVIF is used to test the collinearity problem in the PLS model it is required to be $\leq 5$ but the recommended value is AVIF $\leq 3.3$ [69].Testing the fit model is presented in Table 3 below.

Table 3. Results of Testing the Fit Model

\begin{tabular}{lc}
\hline Average Path Coefficient (APC) & $0.219 ; \mathrm{P} \leq 0.001$ \\
Average R-Squared (ARS) & $0.299 ; \mathrm{P} \leq 0.003$ \\
Average Adjusted $R$-Square (AARS) & $0.285 ; \mathrm{P} \leq 0.007$ \\
Average Block Variance Inflation Factor (AVIF) & 1.049 \\
\hline
\end{tabular}

Source: Processed data, 2020

The test results in this study produce a fit model. Table 3, illustrates that APC, ARS and AARS have a value of $\rho$-value $\leq 0.05$ and AVIF value $\leq 3.3$ which indicates that there is no multicollinearity problem between the proxy and the variables used.

\subsection{Hypothesis test}


This research has two hypotheses to test the direct and indirect test using mediation variables. The results of the influence before and after the mediation variables are included are presented in Table 4 . Table 4 shows that the direct influence of green innovation on firm value has a positive and significant effect on firm value. This supports H1 which states that green innovation influences company value. Financial performance mediates the influence between the green process of innovation and firm value, so that $\mathrm{H} 3$ is accepted.

Table 4. Output Part Least Square (path coefficient dan p value)

\begin{tabular}{|c|c|c|c|}
\hline \multicolumn{4}{|c|}{ Panel A. Direct Effect } \\
\hline $\begin{array}{l}\text { Relationship } \\
\text { variables }\end{array}$ & between & Path Coefficient & $p$-value \\
\hline EP FV & & 0.08 & $0.03 * *$ \\
\hline \multicolumn{4}{|c|}{ Panel B. Indirect Effect } \\
\hline $\begin{array}{l}\text { Relationship } \\
\text { variables }\end{array}$ & between & Path Coefficient & $p$-value \\
\hline $\mathrm{EPFV}$ & & 0.01 & 0.44 \\
\hline EPKK & & 0.15 & $<0.01 * * *$ \\
\hline FP FV & & 0.19 & $<0.01 * * *$ \\
\hline
\end{tabular}

Source: Data processed result using WarpPLS software (2020)

Description: $* * * \rho<0.01, * * \rho<0.05, * \rho<0.1$

Table 4 panel B, the indirect effect / mediation, shows that green innovation has a positive and significant effect on financial performance (path coefficient $=0.15$ and $\mathrm{p}>0.05$ ), means accepting $\mathrm{H} 2$ stating that green innovation influences financial performance. Financial performance has a positive and significant effect on firm value (Path coefficient $=0.19$ and $\mathrm{p}$ value $<0.05$ ), meaning that $\mathrm{H} 4$ is accepted. Financial performance increases the value of the company.

\subsection{The effect of green innovation on Firm Value}

Green innovation has a significant positive effect on company value. This shows that the green innovation carried out by the company is able to increase the value of the company. The results of this study are in line with research conducted by Rubera\&Kirca, (2017); Sucuahi\&Cambarihan (2016), revealed that if innovation is carried out by the company on an ongoing basis, the firm value will be better. A number of companies have carried out green innovation as evidenced by PROPER certification as a structured standard in implementing environmentally friendly programs. When companies express green innovation, the company is considered responsible for the environment. Thus, investor confidence in the company is increasing.

This study also explains that many companies in Indonesia have implemented green innovation. These companies are considered to have the ability to utilize their energy resources efficiently. Thus, the public and stakeholders are interested in buying their products. When the value of the company increases (seen from stock movements), the company's sales also show the same trend.

\subsection{The Effect of Green Innovation on Financial Performance}

Green innovation has a significant positive effect on financial performance. This shows that the better the company's green innovation, the financial performance will also be better. This finding is in line with the results of research by Soewarno et al. (2018); Nishitani et al. (2017) which shows that environmental innovation can improve a company's financial performance. This positive influence is influenced by the number of companies in Indonesia that have carried out green innovation. When the company is considered to have environmental responsibility, the opportunity to increase sales is more open. Investment in environmental improvement will add burden to the company and community sustainability in the short term while increasing financial performance. This statement is in accordance with stakeholder theory that companies that pay attention to the environment have an impact on increasing profits Freeman, (1984); Burnett et al. (2011). The company's commitment to preserve the environment can guarantee the sustainability of the company's business (Soewarno et al., 2018). Based on the results of an assessment from the Ministry of Environment, PROPER participants who are listed on the Indonesia Stock Exchange have carried out their activities based on the concept of environmentally friendly and sustainable growth. This will have a positive impact on investors for companies that comply with environmental regulations. 


\subsection{Influence of Green innovation, Financial Performance and Firm Value}

Financial performance is able to mediate green innovation on company value. This shows that the company's financial performance has an impact on increasing the value of the company. The results of this study support the stakeholder theory that companies must fulfill stakeholder rights related to information on company activities such as pollution, social movements and company business for safety in order to obtain support and face the level of competition between industries Gray et al. (1995); Umrie\&Yuliani, (2014); Warusawitharana, (2015); Sucuahi\&Cambarihan, (2016; Rubera\&Kirca, 2017; Sulastri et al. (2018). Green innovation that has been carried out by the company is positively correlated with the company's internal and external interests. Thus companies become responsive to the environmental conditions in which they operate. One form of the application is the company's participation in environmental programs at the national and international level.

\subsection{Effects of Financial Performance and Firm Value}

Financial performance has a significant positive effect on firm value. This finding indicates that financial performance can increase the value of a company which is seen to be higher in stock prices. High profits from stock prices will attract investors to invest. This condition will positively influence the value of the company. General, (2015); Sabrin et al. (2016); Sucuahi\&Cambarihan, (2016); Usman et al. (2017); Sulastri et al. (2018); Tariq et al. (2019). Sabrin et al. (2016), Provides empirical evidence that profitability has a significant positive effect on firm value (Kurniasari\&Warastuti, 2015). Profitability shows the effectiveness of the company in generating profit levels from managing its assets. Investor's assessment of financial performance influences the company's sustainability in the future. Sabrin et al. (2016), revealed that the higher the profitability, the company has good prospects so that investors will pay more for the company.

\section{Conclusion}

The results of this study support stakeholder theory, companies are required to create environmental sustainability by carrying out various innovations in order to reduce negative impacts on the environment, revealed that the survival and financial performance is determined by the innovation strategy undertaken by the company and supports government programs to make the industrial estate environmentally friendly.

Green innovation is as a form of environmental strategy in financial and non-financial investment. One side of green innovation is considered a burden for companies, especially in developing countries. On the other hand will increase profits in the future, Financial performance is the main standard assessment of investors for companies in the internal and external environment. Guenster et al. revealed that green innovation plays a role in increasing company value. This is caused, because the company uses technology that is safe so that it does not cause negative impacts on the environment.

This study has limitations that can be taken into consideration for further research. First, the sample used is limited to mining companies. Second, the financial performance in this study only uses ROA (Return On Assets)). Third, the green innovation proxy is limited to companies that obtain PROPER. This can be a consideration for other studies interested in taking the topic of green innovation. Suggestions in this study are: first, further research in order to be able to add samples other than mining companies. Second, further research can use financial performance measures other than ROA. Third, further research can add measurement variables to green innovation, such as ISO 14001 and content analysis.

\section{References}

1. Y. Hwang, D. Kim, B. Jang, and H. K. Choi, "The Mediation Effect of Traffic Locus of Control on the Relationships between Psychological Characteristics and Reckless Driving of Drivers," 9th Int. Conf. Inf. Commun. Technol. Converg. ICT Converg. Powered by Smart Intell. ICTC 2018, pp. 996-998, 2018, doi: 10.1109/ICTC.2018.8539446.

2. H. Nain, U. Jadon, and V. Mishra, "Performance investigation of kerr effects on to WDM fiber optical networks," 2016 IEEE Int. Conf. Recent Trends Electron. Inf. Commun. Technol. RTEICT 2016 - Proc., no. 3, pp. 2018-2022, 2017, doi: 10.1109/RTEICT.2016.7808193.

3. J. Zhu, Y. Wang, and L. Q. Yi, "The effect of calling orientations on work engagement of employees in securities company: An intermediary model of mediation," IEEE Int. Conf. Ind. Eng. Eng. Manag., vol. 2017-December, pp. 2194-2198, 2018, doi: 10.1109/IEEM.2017.8290281.

4. L. Xie, W. Zhang, and Y. Peng, "Mediation effect of brand relationship quality between airline brand experience and customer citizenship behavior," 11th Int. Conf. Serv. Syst. Serv. Manag. ICSSSM 2014 - 
Proceeding, pp. 1-5, 2014, doi: 10.1109/ICSSSM.2014.6874080.

5. W. Shi and E. Wang, "Organizational factors and safety: The mediation effects of organizational processes," Proc. - 2010 3rd Int. Conf. Biomed. Eng. Informatics, BMEI 2010, vol. 6, no. Bmei, pp. 2486-2488, 2010, doi: 10.1109/BMEI.2010.5639677.

6. J. Wei, X. R. Peng, and Y. Zhang, "CSR strategy, green innovation, and firm performance: A conceptual framework," 2012 Int. Symp. Manag. Technol. ISMOT 2012, pp. 482-485, 2012, doi: 10.1109/ISMOT.2012.6679519.

7. X. Xie, J. Huo, G. Qi, and K. X. Zhu, "Green Process Innovation and Financial Performance in Emerging Economies: Moderating Effects of Absorptive Capacity and Green Subsidies," IEEE Trans. Eng. Manag., vol. 63, no. 1, pp. 101-112, 2016, doi: 10.1109/TEM.2015.2507585.

8. M. Tantayanubutr, "Impact of Green Innovation towards E conomic P erformance of F ood I ndustrial F irms A pplying Green Industry A pproach under Green Industry Project of Ministry of Industry Thailand," pp. 56-60, 2016.

9. K. X. Bi, S. F. Yang, and J. Li, "Study on influential factors of low-carbon performance of manufacturing green innovation system," Int. Conf. Manag. Sci. Eng. - Annu. Conf. Proc., no. 2004, pp. 1584-1590, 2012, doi: 10.1109/ICMSE.2012.6414384.

10. Z. Wu, Z. Yang, J. Sun, and Y. Zou, “Alignment between Enterprise Green Supply Chain and Green Information System: An Analysis of Four Cases," IEEE Int. Conf. Ind. Eng. Eng. Manag., vol. 2019December, pp. 904-908, 2019, doi: 10.1109/IEEM.2018.8607759.

11. J. Zhang and W. Tan, "The study of performance evaluation index of green supply chain and comprehensive evaluation model," 2010 Int. Conf. E-Product E-Service E-Entertainment, ICEEE2010, pp. 10-13, 2010, doi: 10.1109/ICEEE.2010.5660750.

12. C. H. Chang, "Green innovation performance: Antecedent and consequence," PICMET Portl. Int. Cent. Manag. Eng. Technol. Proc., 2011.

13. I. H. Tekin and D. F. Kocaoglu, "A Bibliometric analysis on Green Innovations, Green Investments and Green Venture Capital,” PICMET Portl. Int. Cent. Manag. Eng. Technol. Proc., no. April 2009, 2011.

14. Bakaruddin, Z. Azmi, and B. H. Hayadi, "Design of expert system to determine stock investment using forward chaining method," J. Adv. Res. Dyn. Control Syst., vol. 10, no. 7 Special Issue, pp. 1869-1873, 2018.

15. M. T. I. Rumengan, J. Rumengan, and ..., “... With Work Motivation As Intervening Variables To Performance of University Employees Batam Using Sem-Pls (Partial Least Square ...," ... Stud. Manaj. ..., vol. 24, no. 06, pp. 5579-5589, 2020, [Online]. Available: http://ejurnal.univbatam.ac.id/index.php/Manajerial/article/view/232. 